\title{
EXPERIMENTAL AND THEORETICAL STUDY ON MAXIMUM REINFORCEMENT RATIOS OF HIGH STRENGTH CONCRETE FLEXURAL BEAMS
}

Khairy Hassan Abdelkareem

Civil Engineering Department, Faculty of Engineering, Assiut

University, Assiut, EGYPT

(Received December 14, 2006 Accepted February 1, 2007)

In the current study, experimental and analytical analysis were carried out to propose models for the maximum reinforcement ratios for high strength concrete flexural beams and to compare the behavior of HSC beams with normal strength concrete beams with respect to this point of view. The behavior is represented by failure mode, ultimate load, deflection and strain. The failure mode of HSC beams is relatively different than that of normal strength beams and this is mainly due to the higher degree of brittleness of HSC. High strength beams require more quantity of steel reinforcement to achieve the ductility. Using HSC leads to an increase of the cracking and ultimate loads of beams and to a decrease of ductility. The steel reinforcement of HSC beams should be increased in such a way that yielding of steel should occur first before crushing of concrete to avoid brittle failure. From the given results of failure mode, load deflection relations and from recording the propagation of cracks and failure mode of beams and following the concept of the required steel reinforcement which is given by the code for normal strength concrete, the required reinforcement of HSC flexural beams is determined and given by equations 4 and 5 in the text. The equations are applicable to all grades of concrete (normal and high strength concrete).

Analytical analysis is carried out to consider the effect of size of cross section on the required reinforcement. Nonlinear plane stress finite element model is utilized to give the required steel reinforcement considering the size effect. Based on experimental and theoretical results and by using parametric analysis and curve fitting, a model of the maximum required steel reinforcement of high strength concrete flexural beams considering the effect of size is recommended and represented by equation 15 in the text. The model is recommended to be used in the design of beams.

KEYWORDS: High Strength and normal strength, Flexural beams, Maximum Requirements of steel reinforcement, Size Effect, Failure Mode, Experimental and finite element analysis 


\section{INTRODUCTION}

The use of high strength concrete (HSC) in construction is widely used nowadays due to many advantages such as; it allows a self weight reduction, a decrease of reinforcing steel bars and a cost saving. HSC can be produced by careful selection of ingredients and mix proportions, use of pozzolanic additives and super plasticizers and with the use of low w/c ratios. Thus it is easy to get such concrete with high quality control in production and casting [1,2]. It should be mentioned that most of researchers consider that concrete of compressive strength equal to or more than $40 \mathrm{MPa}$ is HSC. The practical applications of HSC have preceded full knowledge of HSC material properties and the behavior of structural members constructed with the material. Although HSC has been increasingly used in the construction in the last few years, much more study is still needed for better understanding of its behavior. An increase in the strength of concrete is directly associated with an improvement in most of its properties, in special the durability, but this also produces an increase in its brittleness and smoother crack surfaces which affects significantly the shear strength. The significant problem concerning the use of high strength concrete is its increased brittleness with higher strength. Ductility level of HSC structural member is low and hence its use is not widespread in flexural members.

There are few researches concerning the amount of steel reinforcement of flexural beams. In Ref. [3] the authors studied minimum flexural ductility design of HSC beams. It is proposed that the usual method of achieving the minimum level of flexural ductility in reinforced concrete beams, by either limiting the tension steel ratio or the neutral axis depth to below a fixed maximum values, is no longer a suitable approach. Bosco [4] carried out a study on minimum reinforcement of HSC beams based on the condition of simultaneous first cracking and steel yielding.

In some codes $[4,5,6]$ the required amount is established on the basis of the ratio between the computed stresses in the concrete and steel. Other codes $[4,5,6]$ take into account only the steel yield strength. Italian code [4] and Russian code [4] fix a minimum percentage of steel independently of any geometrical and mechanical feature. It is possible to consider the beam size effect on the required steel percentage, through the concept of fracture mechanics. The fracture mechanics model defines a brittleness number $N_{p}$, which is considered as a measure of the brittleness or ductility of the test. $\mathrm{N}_{\mathrm{p}}$ is a function yield strength $f_{y}$, concrete fracture toughness $K_{I C}$, steel percentage As/A and beam depth $[4,7]$.

\section{Purpose of the Study}

The Egyptian code does not include provisions for the required flexural reinforcement of HSC beams. The formulae given by the international codes are not adequate for HSC beams because they neglect most of the factors especially 
the effect of size. In the current study, experimental and theoretical investigations are carried out to suggest the required reinforcement of HSC flexural beams. The purposes of the study are to investigate the behavior of HSC beams and to compare such behavior with that of normal strength concrete beams and to suggest the required flexural reinforcement of HSC beams considering the effect of size. The study is divided into two parts; experimental and theoretical.

\section{PART I: EXPERIMENTAL ANALYSIS}

\section{Experimental Program and System of Loading}

To achieve the purposes of the current study, eighteen specimens were prepared and constructed at the Laboratory of reinforced concrete and strength of materials at Civil Department of Assiut University. The specimens were divided into three groups; A, B and C. The difference between the three groups is the grade of concrete. Table 1 summarizes the details and description of each specimen of all the groups. Fig. 1 illustrates the system of loading, details, dimensions and reinforcement of the tested beams. All the specimens were tested after 28 days after casting. A testing machine of 60 tons capacity was utilized. All the specimens were tested under two-point static loading system. Mid-span deflection and strains were recorded at each loading increment, which was kept as $100 \mathrm{~kg}$. Figure 2 illustrates the loading system and the test setup. The obtained results are represented by the failure mode, deflections and strains.

Table 1 Details and Description of Test Specimens

\begin{tabular}{|c|c|c|c|c|c|c|c|}
\hline Group & \multicolumn{7}{|c|}{ Details and description } \\
\hline \multirow{4}{*}{$\begin{array}{c}\text { Group } \\
\text { A } \\
\text { C } 250\end{array}$} & Beam & A - 1 & $A-2$ & A - 3 & A - 4 & A - 5 & $A-6$ \\
\hline & Reinft. & $2 \phi 8 m m$ & \multicolumn{4}{|c|}{$2 \phi 10 m n \phi 12 m m 3 \phi 12 m m ~ 4 \phi 12 m m$} & $5 \phi 12 m m$ \\
\hline & & mild & HTS & HTS & HTS & HTS & HTS \\
\hline & $\% \mathrm{~A}_{\mathrm{s}}$ & 0.64 & 1.0 & 1.45 & 2.17 & 2.9 & 3.62 \\
\hline \multirow{4}{*}{$\begin{array}{c}\text { Group } \\
\text { B } \\
\text { C } 500\end{array}$} & Beam & B - 1 & $\mathrm{~B}-2$ & B - 3 & B - 4 & B - 5 & $B-6$ \\
\hline & Reinft. & $2 \phi 8 m m$ & \multicolumn{4}{|c|}{$2 \phi 10 m n \phi 12 m m ~ 3 \phi 12 m m ~ 4 \phi 12 m m$} & $5 \phi 12 m m$ \\
\hline & & mild & HTS & HTS & HTS & HTS & HTS \\
\hline & $\% \mathrm{~A}_{\mathrm{s}}$ & 0.64 & 1.0 & 1.45 & 2.17 & 2.9 & 3.62 \\
\hline \multirow{4}{*}{$\begin{array}{c}\text { Group } \\
\text { C } \\
\text { C } 700\end{array}$} & Beam & C - 1 & $\mathrm{C}-2$ & $\mathrm{C}-3$ & $C-4$ & $\mathrm{C}-5$ & $\mathrm{C}-6$ \\
\hline & Reinft. & $2 \phi 8 m m$ & \multicolumn{4}{|c|}{$2 \phi 10 m n \not 2 m m ~ 3 \phi 12 m n h ~ 4 \phi 12 m m$} & $5 \phi 12 m m$ \\
\hline & & mild & HTS & HTS & HTS & HTS & HTS \\
\hline & $\% \mathrm{~A}_{\mathrm{s}}$ & 0.64 & 1.0 & 1.45 & 2.17 & 2.9 & 3.62 \\
\hline
\end{tabular}

* Mild steel was used as compression steel. For this reason, compression steel was not considered in the analysis. 
Materials: Three grades of concrete are used as follows:

1- Normal strength concrete. Concrete mix design was carried out to produce normal strength concrete. The proportions are illustrated in table 2 as follows:

Table 2: Concrete Mix proportions of Normal Strength Concrete

\begin{tabular}{|l|l|l|l|}
\hline Cement $\mathrm{kg} / \mathrm{m}^{3}$ & Sand $\mathrm{kg} / \mathrm{m}^{3}$ & Gravel kg/m & water Litre $/ \mathrm{m}^{3}$ \\
\hline 350 & 670 & 1200 & $165(\mathrm{w} / \mathrm{c}=0.47)$ \\
\hline
\end{tabular}

A total of 18 standard cubes was prepared and tested after 28 days. The dimensions of the cube are $15 \times 15 \times 15 \mathrm{~cm}$. The average concrete strength of cubes is $250 \mathrm{kgf} / \mathrm{cm}^{2}$.

2-High strength concrete (HSC). Two grades of high strength concrete were produced in the study. The concrete mix proportions by weight are given in table 3.

Table 3: Concrete Mix proportions to produce High Strength Concrete

\begin{tabular}{|c|c|c|c|c|c|c|c|}
\hline Grade & $\begin{array}{l}\text { cement } \\
\mathrm{kg} / \mathrm{m}^{3}\end{array}$ & $\begin{array}{l}\text { Sand } \\
\mathrm{kg} / \mathrm{m}^{3}\end{array}$ & & $\begin{array}{l}\mathrm{kg} / \mathrm{m}^{3} \\
0-20 \mathrm{~mm}\end{array}$ & $\begin{array}{l}\text { Silica } \\
\text { fume } \\
\mathrm{kg} / \mathrm{m}^{3}\end{array}$ & $\begin{array}{l}\text { Sikament } \\
\mathrm{FF}-3 \\
\mathrm{~kg} / \mathrm{m}^{3}\end{array}$ & $\begin{array}{l}\text { Water } \\
\text { Litre/m³ }\end{array}$ \\
\hline C700 & 500 & 525 & 600 & 600 & 90 & 17 & $125(0.25)$ \\
\hline C900 & 450 & 600 & 600 & 600 & 70 & 14 & $165(0.37)$ \\
\hline
\end{tabular}

The coarse aggregate is crushed basalt with 10 and $20 \mathrm{~mm}$ nominal size. Natural sand was used as fine aggregate. Ordinary Portland cement was used (Assiut Cement) in all concrete mixes. For each of $\mathbf{C ~} \mathbf{7 0 0}$ and $\mathbf{C ~ 5 0 0}$, a total of 18 standard cubes was prepared and tested after 28 days for each grade. The average concrete strength of standard cubes is 700 and $500 \mathrm{kgf} / \mathrm{cm}^{2}$. These concrete mixes were used by the author in a previous study [2]. High strength ribbed bars of grade 36/52 and mild steel bars of grade 24/35 are used in the study. 


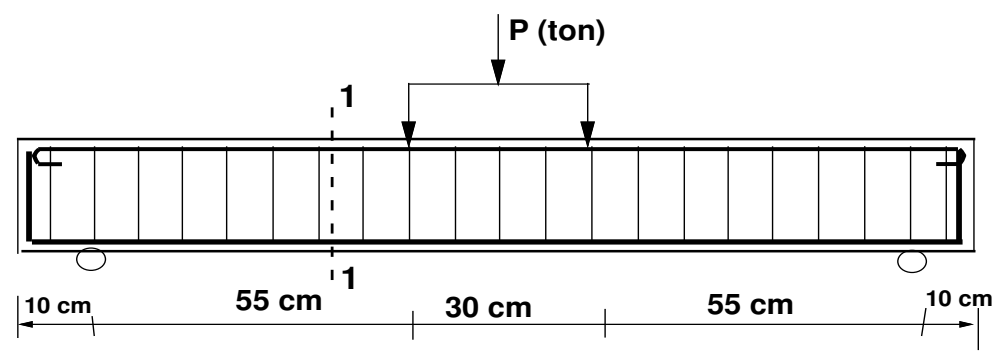

$2 \oint 8 \mathrm{~mm}$ (mild bars)

\begin{tabular}{|ll}
$2 \phi 8 \mathrm{~mm}$ for A-1, B-1, C-1 & $2 \phi 10 \mathrm{~mm}$ for A-2, B-2, C-2 \\
$2 \phi 12 \mathrm{~mm}$ for A-3, B-3, C-3 & $3 \phi 12 \mathrm{~mm}$ for A-4, B-4, C-4 \\
$4 \phi 12 \mathrm{~mm}$ for A-5, B-5, C-5 & $5 \phi 12 \mathrm{~mm}$ for A-6, B-6, C-6 \\
\hline
\end{tabular}

Stirrups are of diameter $6 \mathrm{~mm}$ (mild steel)

The spacing between stirrups in the middle part $=7.5 \mathrm{~cm}$

The spacing between stirrups in the distance $55 \mathrm{~cm}=6.5 \mathrm{~cm}$
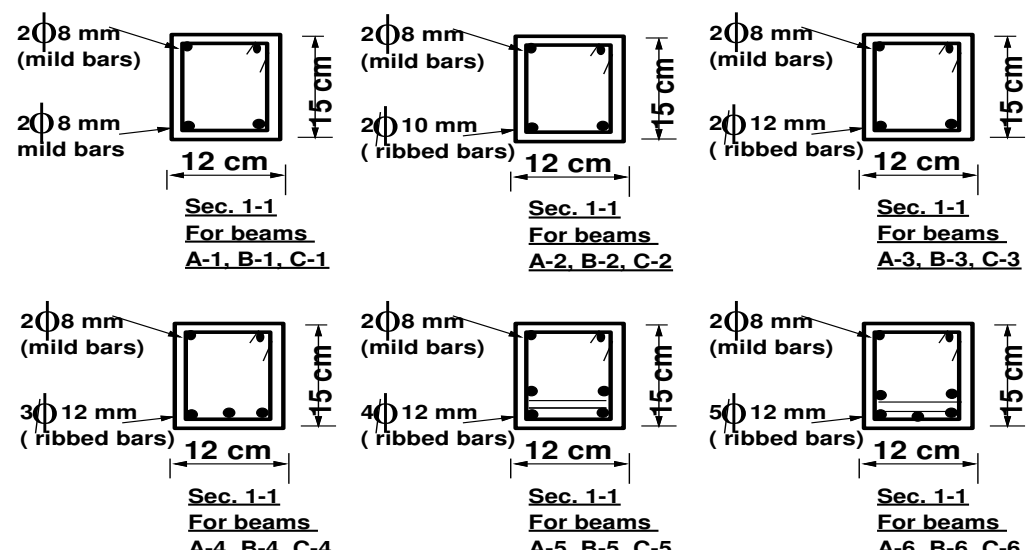

$2 \phi 8 \mathrm{~mm}$

A-2, B-2, C-2

A-3, B-3, C-3

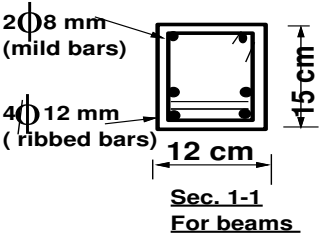

$2 \phi 8 \mathrm{~mm}$

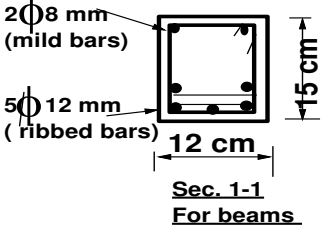

A-4, B-4, C-4

A-5, B-5, C-5

A-6, B-6, C-6

Position of strain gauge on steel bar

Fig. 1 System of loading, details, dimensions and reinforcement of test specimens
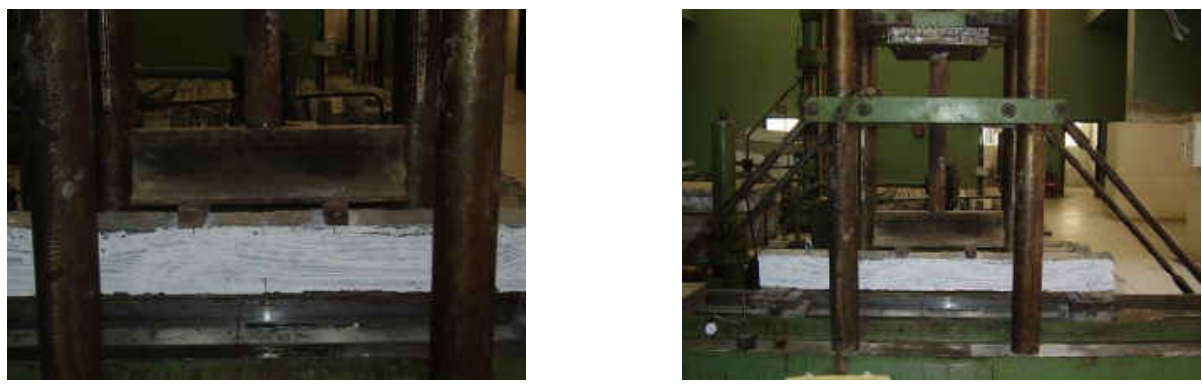

Fig. 2 Test Setup and system of loading 


\section{RESULTS AND ANALYSIS}

\section{With Respect to Failure mode}

Photos 1 to 6 illustrate the final failure modes of specimens A-1 to A-6 of Group A in which the grade of concrete is $250 \mathrm{~kg} / \mathrm{cm}^{2}$. The following points are to be summarized:

Severe flexural failure mode occurred for specimen A-1 which has steel percentage of $0.64 \%$. In specimen A-2, with steel percentage of $1.0 \%$, flexural failure occurred associated with spalling of concrete cover in the compression surface. The severity of flexural failure was reduced in specimen A-3 of steel percentage of $1.45 \%$. Failure mode of specimen A-4 of steel percentage of 2.17 is compression failure of concrete at the top surface associated with some flexural cracking. Similar compression failure was recorded for specimens A-5 and A-6, which have steel percentages of 2.9 and $3.62 \%$ respectively. As the steel percentage increases, flexural cracking is reduced and after a certain steel ratio, the failure mode is changed to compression failure. This is normal conclusion; because as steel ratio is small, yielding of steel occurs before crushing of concrete and as steel ratio is high, crushing of concrete occurs before yielding of steel. At a certain steel ratio, balanced failure occurs.

Photos 7 to 12 illustrate the final failure modes of specimens B-1 to B-6 of Group B in which the concrete is HSC of grade $500 \mathrm{~kg} / \mathrm{cm}^{2}$. The following points are summarized:

Severe flexural failure mode occurred for specimen B-1, which has steel percentage of $0.64 \%$. The severity of flexural cracking of B-1 (HSC) is higher than that of A-1 (normal strength) and this is due to the brittleness of HSC. In specimen B-2, with steel percentage of $1.0 \%$, flexural failure occurred associated with spalling of concrete cover in the compression surface and this is similar to A-2 of Group A. The severity of flexural failure was reduced in specimen B-3 of steel percentage of $1.45 \%$. Failure mode of B-4 of steel percentage of 2.17 is compression failure of concrete at the top surface associated with some flexural cracking. Similar compression failure was recorded for specimens B-5 and B-6, which have steel percentages of 2.9 and $3.62 \%$ respectively. As the steel percentage increases, flexural cracking is reduced and after a certain steel ratio, the failure mode is changed to compression failure. Comparing groups $\mathrm{A}$ and $\mathrm{B}$, it is concluded that HSC beams need bigger amount of reinforcement.

Photos 13 to 16 illustrate the final failure modes of specimens C-1 to C-6 of Group C in which HSC of grade $700 \mathrm{~kg} / \mathrm{cm}^{2}$ is used. The following points are summarized:

Severe flexural failure mode occurred for specimens C-1, which has steel percentage of $0.64 \%$ associated with spalling of concrete cover in compression. The severity of flexural cracking of C-1 (HSC) is higher than that of B-1 (C500) and A-1 (normal strength) and this is due to the brittleness of HSC. In 
specimen C-2, with steel percentage of $1.0 \%$, flexural failure occurred associated with spalling of concrete cover in the compression surface and this is similar to B-2 of group B and A-2 of Group A. The severity of flexural failure was reduced in specimen B-3 of steel percentage of $1.45 \%$. Failure mode of specimen C-4 of steel percentage of 2.17 is compression failure of concrete at the top surface associated with some flexural cracking. Similar compression failure was recorded for specimens C-5 and C-6 which have steel percentages of 2.9 and $3.62 \%$ respectively. Comparing the similar beams of the same steel percentage in the different groups, it is clear that as the strength of concrete increases, its brittleness increases and hence the ductility should be increased. This can be done through many provisions such as increasing the percentage of reinforcement, admixtures, fibres,....etc.
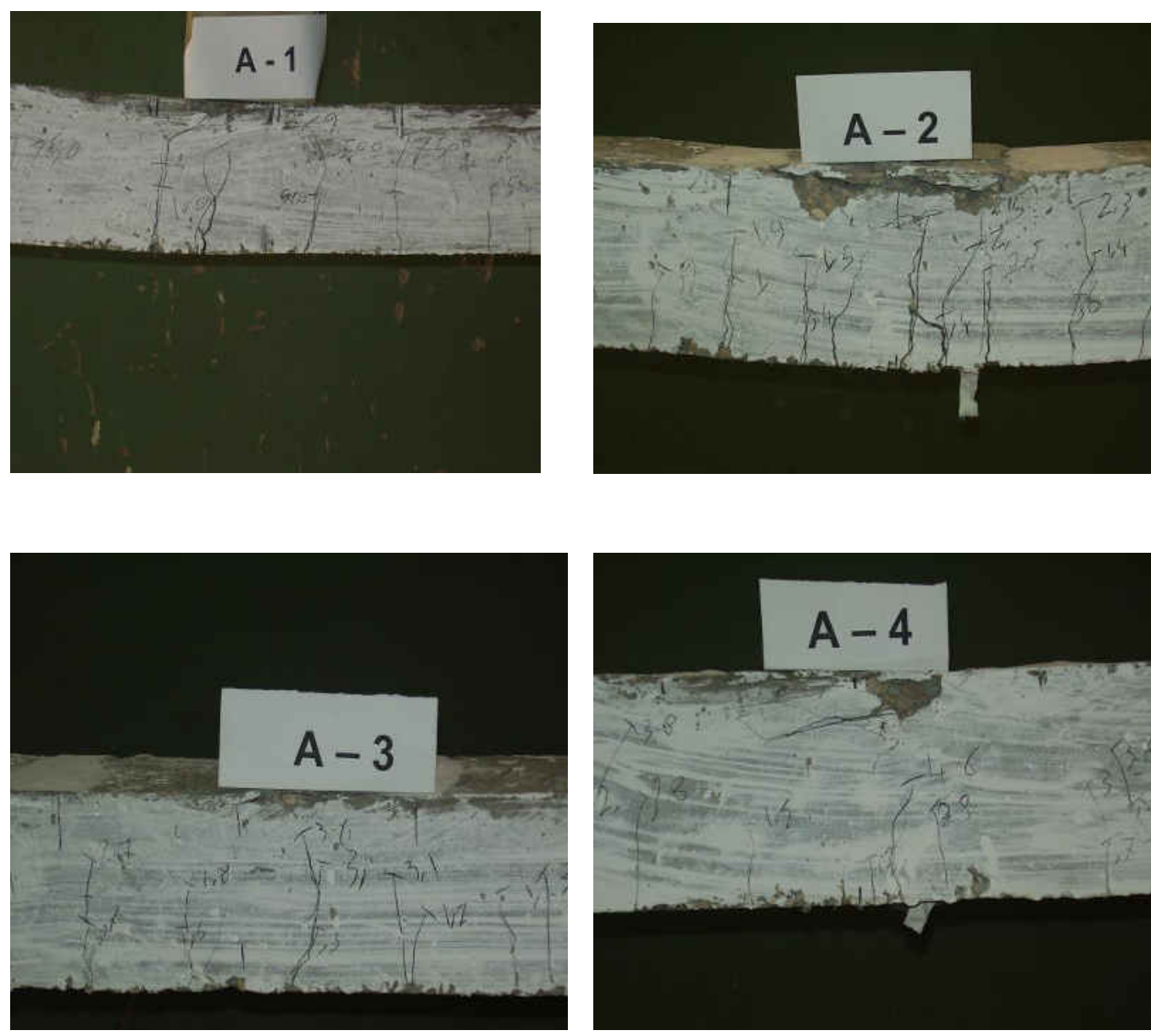

Photos of Group A 


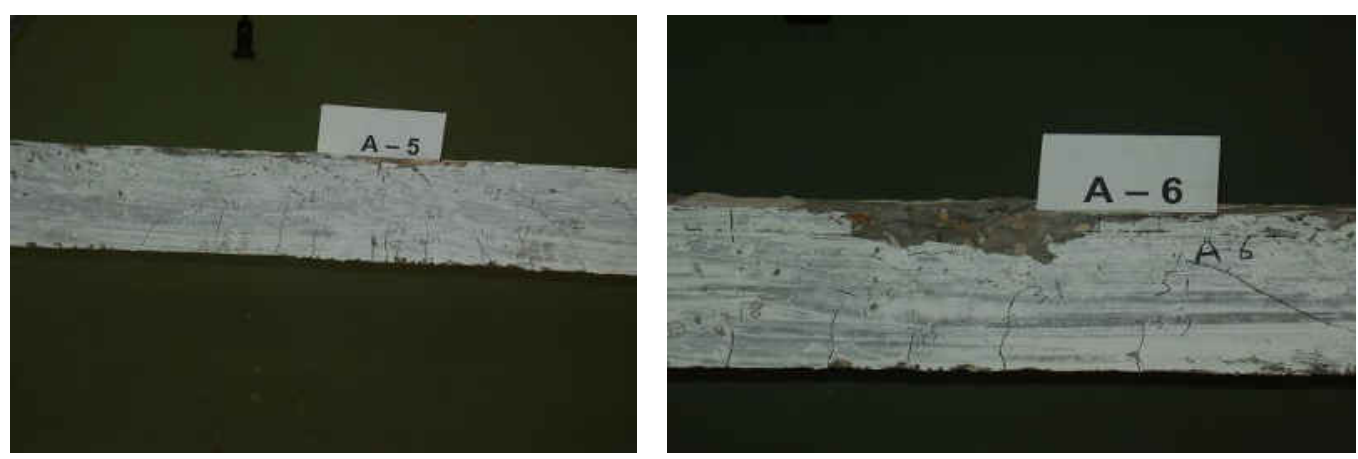

Photos of Group A (cont.)
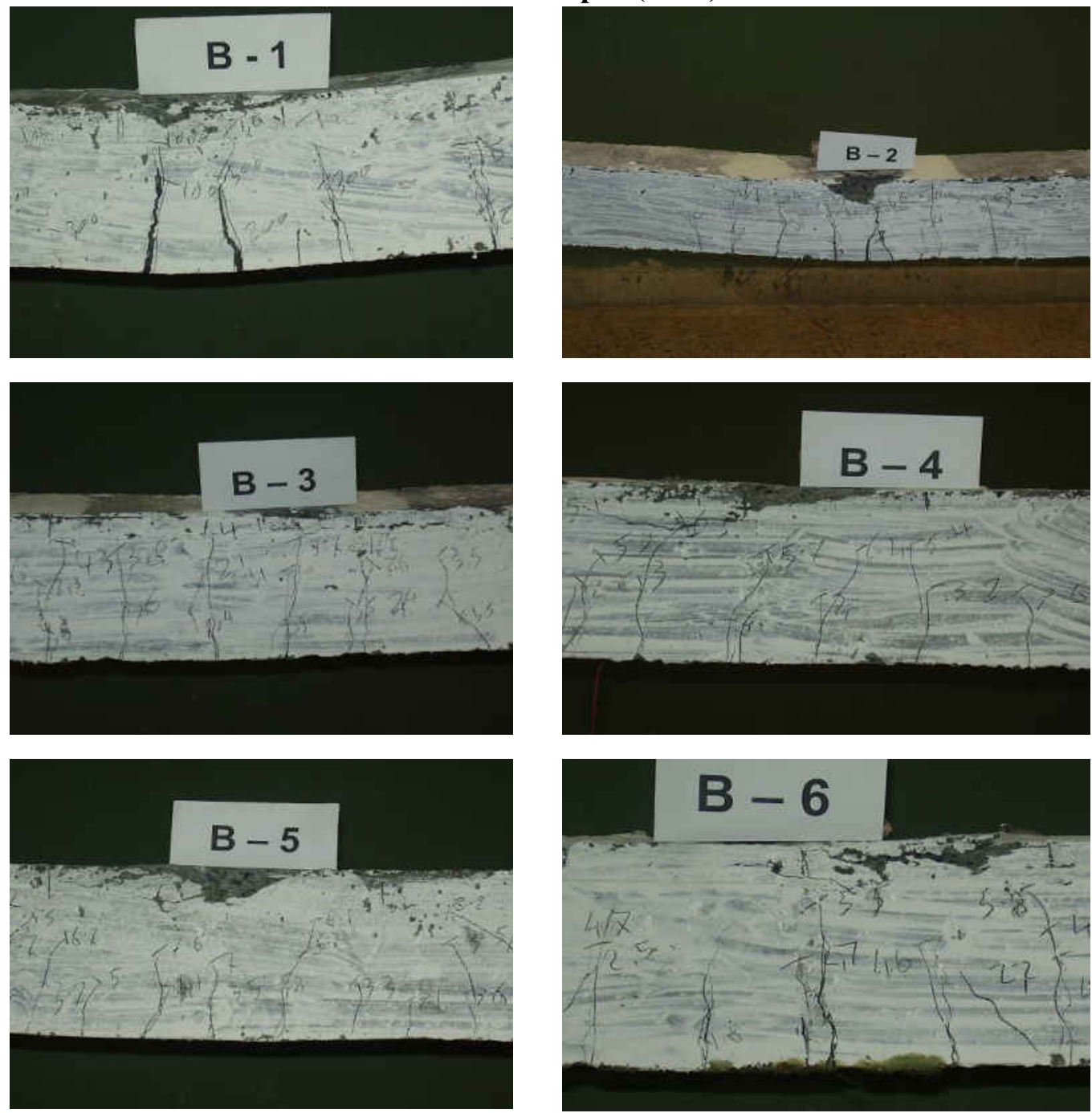

Photos of Group B 

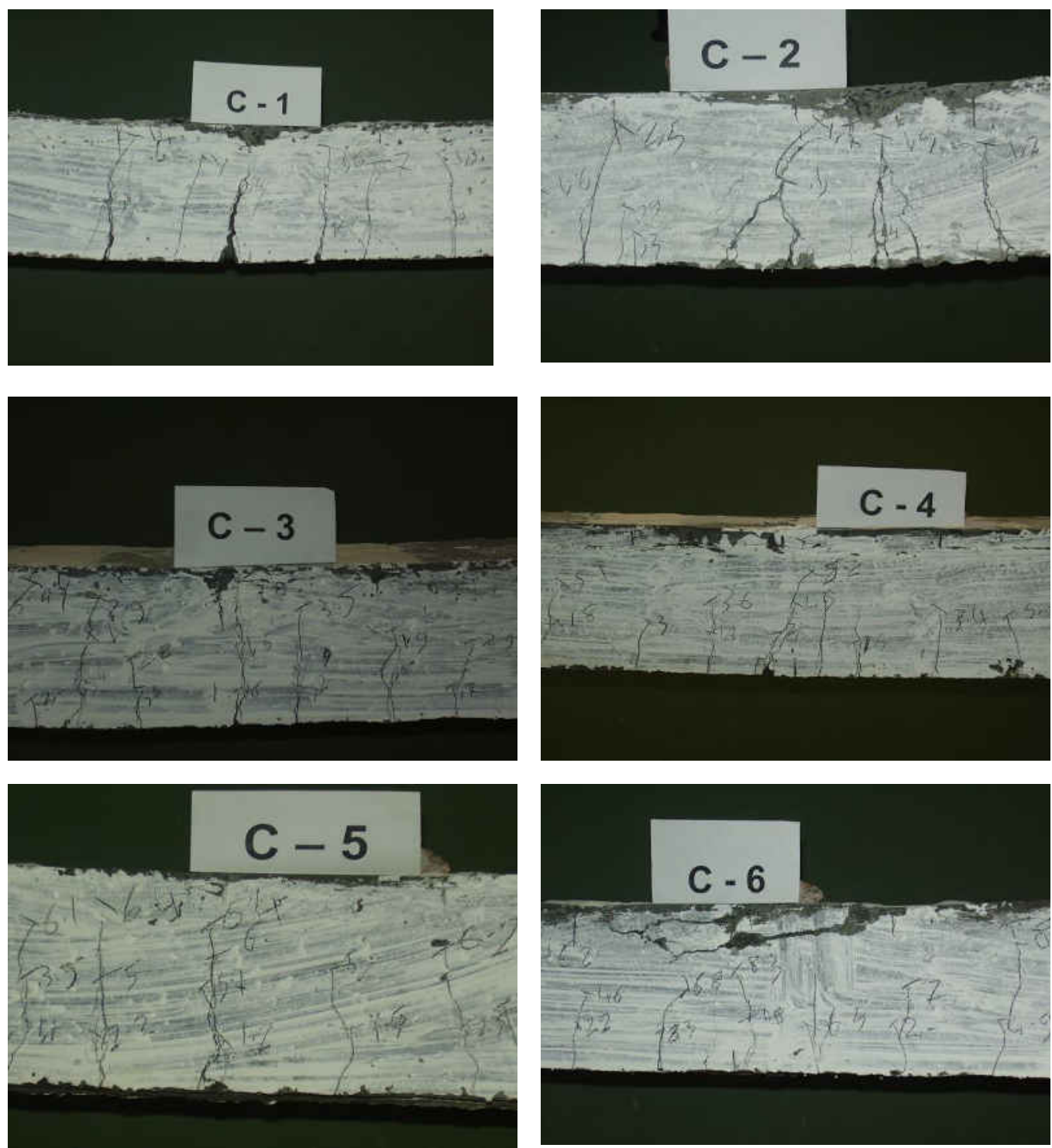

Photos of Group C

\section{With Respect of Load Deflection Relation}

Firstly, we investigate the effect of steel reinforcement on load deflection diagrams for the same grade of concrete. Fig. 3 illustrates the load deflection diagrams for specimens of group A of normal strength concrete. It is clear that as percentage of steel increases, ultimate strength increases, but maximum deflection decreases for specimens A-3, A-4 and A-5 and the biggest deflection is recorded for specimen A-2 of steel ratio of $1.0 \%$, considering the change of failure mode with increase of steel ratio. Fig. 4 illustrates the load deflection diagrams for specimens of group B of HSC (C500). It is clear that as percentage 
of steel increases, ultimate strength increases, but maximum deflection decreases and the biggest deflection is recorded for specimen A-2 of steel ratio of $1.0 \%$, considering the change of failure mode with increase of steel ratio. Thus, there is a change of the behavior of HSC beams as compared with that of normal strength concrete. Fig. 5 illustrates the load deflection diagrams for specimens of group C of HSC (C700). The behavior of group C is approximately similar to that of group B. Note that the behavior of beams $\mathrm{C}-1$ and C-2 is similar, beams C-3 and C-4 is similar and C-5 and C-6 is similar considering the failure mode of such beams.

Secondly, we investigate the effect of changing the grade of concrete on load deflection diagrams for the same steel reinforcement. Fig. 6 illustrates load deflection diagrams for beams A-1, B-1 and C-1, which have the same steel reinforcement $0.64 \%$ and with different grades (C250, 500 and 700). Figs. 7, 8, $9,10,11$ illustrate similar diagrams for $[\mathrm{A}-2, \mathrm{~B}-2$ and C-2 with steel percentage of $1.0 \%$ ], [A-3, B-3 and C-3 with steel percentage of $1.45 \%$ ], [A-4, B-4 and C-4 with steel percentage of $2.17 \%$ ], [A-5, B-5 and C-5 with steel percentage of $2.9 \%$ ] and [A-6, B-6 and C-6 with steel percentage of $3.62 \%$ ]. All these figures give a comparison between the behavior of beams, which have similar reinforcement but with different concrete grades. Also, the figures illustrate the effect of HSC on the behavior of beams as compared with the beams of ordinary strength. It is clear that using HSC generally improves the ultimate load of the beams but it reduces its ductility for most of the beams. The beams of group B of HSC (C500) usually have higher load capacity and higher ductility than that of group A (C250). In addition, beams of group B usually have higher ultimate load and higher ductility than that of group C. This indicates that beams of group $\mathrm{C}$ should have bigger quantity of steel reinforcement to improve the behavior. For HSC grades, bigger quantity of steel reinforcement is needed.

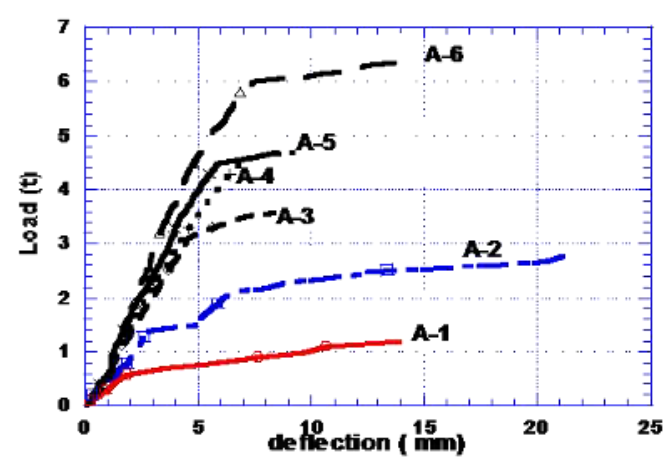

Fig.3 load deflection curves of group A

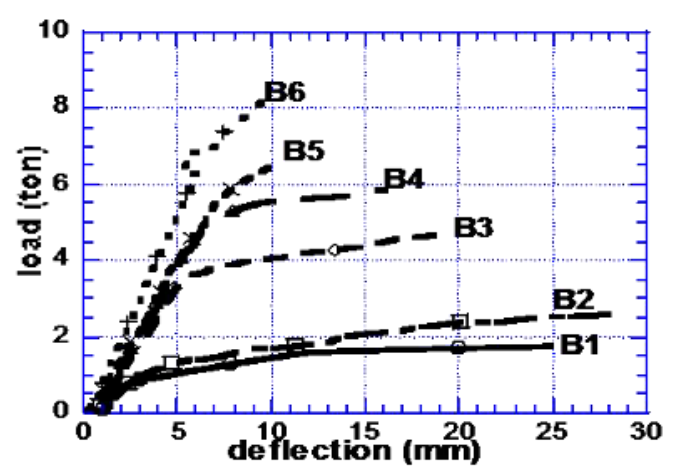

Fig. 4 Load deflection curves of group B 


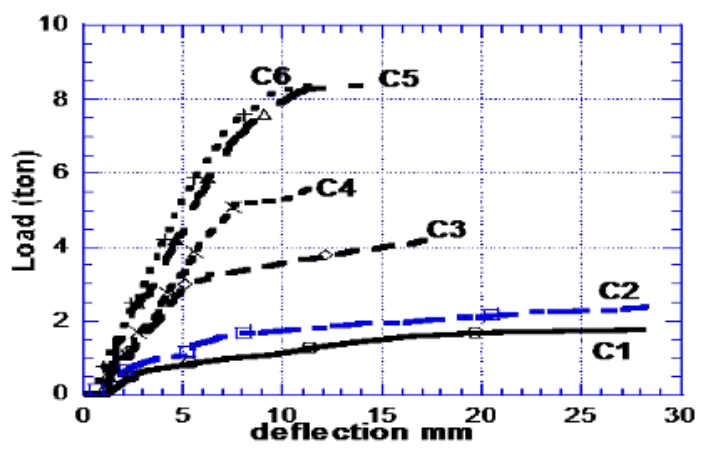

Fig. 5 Load deflection curves of group C

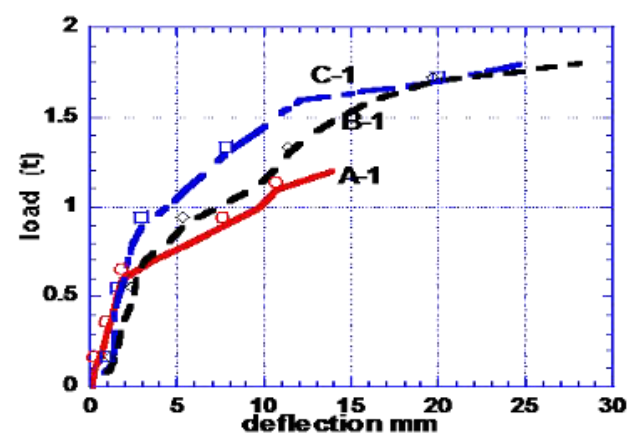

Fig.6 Load deflection relations for A-1, B-1, C-1

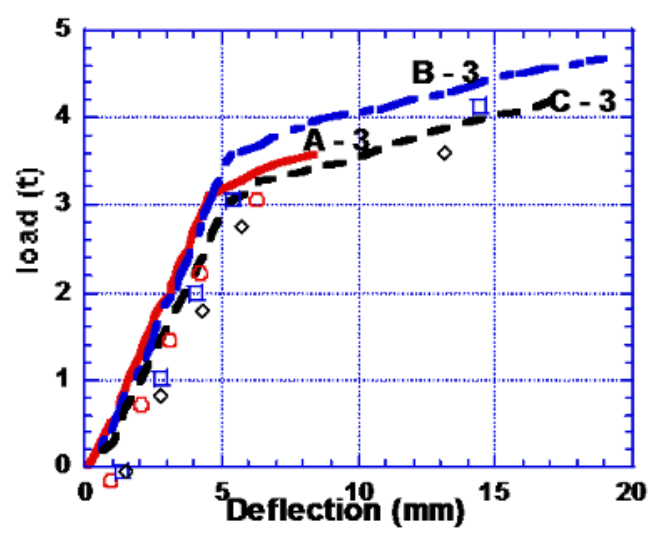

Fig. 8 Load deflection relations for A-3, B-3, C-3

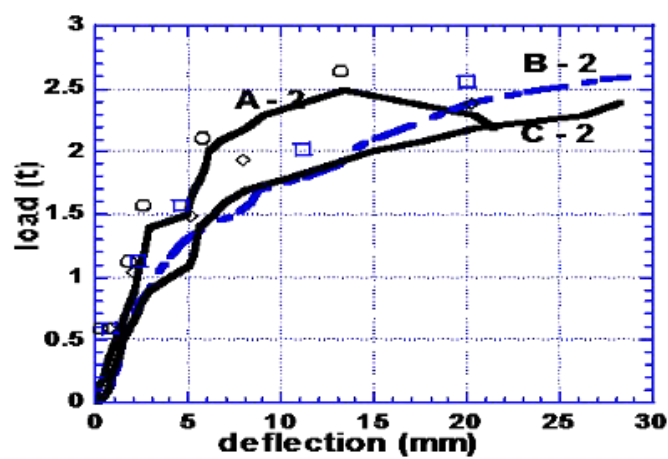

Fig.7 Load deflection relations for A-2, B-2, C-2

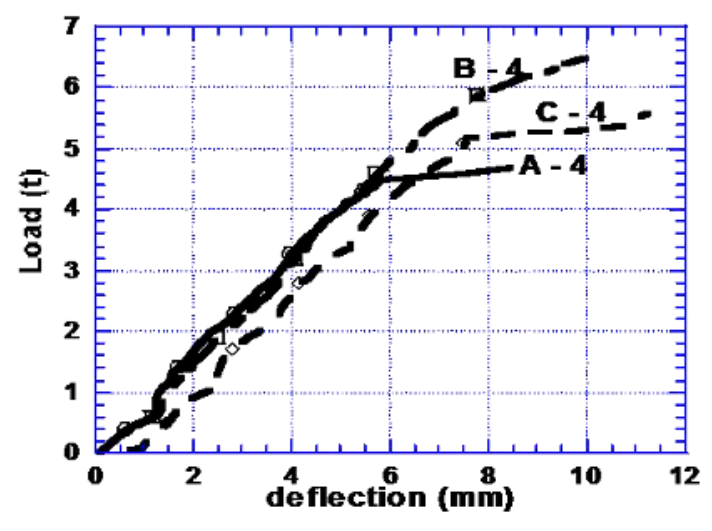

Fig. 9 Load deflection relations for A-4, B-4, C- 4 


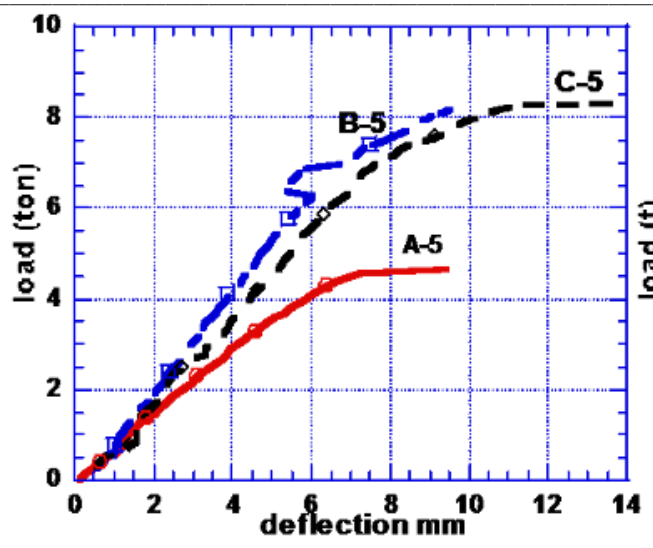

Fig. 10 Load deflection relations for A-5, B-5, C-5

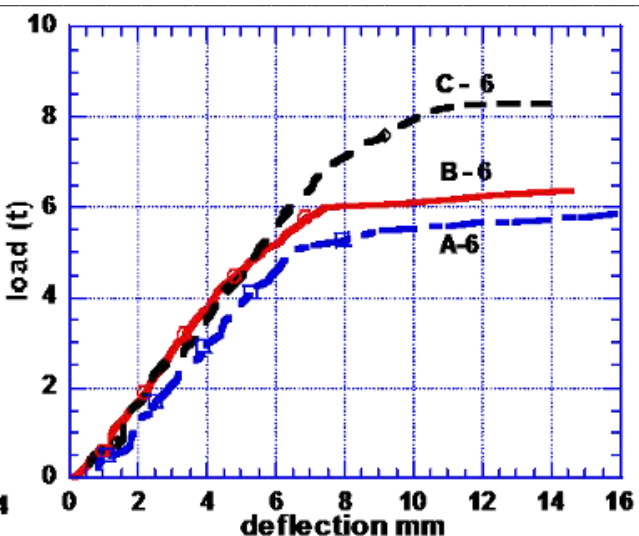

Fig. 11 Load deflection relations for A-6, B-6, C-6

\section{With Respect to Load strain diagram}

Following the same way, we plotted the relations between load and strain of steel reinforcement. Firstly, we investigate the effect of percentage of steel reinforcement on load strain diagrams for the same grade of concrete. Fig. 12 illustrates the load strain diagrams for specimens of group A of normal strength concrete (C250). The highest load was recorded for specimen A-3 with steel reinforcement of $1.0 \%$ and the minimum load associated with maximum strain was recorded for beam A-6 of steel ratio of $3.62 \%$. Fig. 13 illustrates the load strain diagrams for specimens of group B of HSC (C500). On Contrary with group A, minimum load was recorded for beam B-2 (1.4\%) and maximum load was recorded for beams B-5 and B-6. This indicates that HSC beams require bigger quantity of steel reinforcement. Fig.14 illustrates the load strain diagrams for specimens of group C of HSC (C700). Minimum load was recorded for beam C-2 (1.0\%) and maximum load was recorded for beams C-6.

Secondly, we investigate the effect of changing the grade of concrete on load strain diagrams for the same steel reinforcement. Fig.15 illustrates load strain diagrams for Beams A-2, B-2 and C-2, which have the same steel reinforcement $1.0 \%$ and with different grades $(250,500$ and 700$)$. Even there is small difference in the ultimate load, the strain of steel changes significantly. Lower strain was measured for A-2 and biggest strain was for C-2. Fig.16 illustrates load strain diagrams for Beams A-3, B-3 and C-3 (steel reinforcement 1.45\%). Fig.17 illustrates load strain diagrams for Beams A-4, B-4 and C-4 (steel reinforcement $=2.17 \%$ ). Fig.18 illustrates load strain diagrams for Beams A-5, B-5 and C-5 (steel reinforcement $2.9 \%$ ), noting that highest strain was recorded for B-5. Fig. 19 illustrates load strain diagrams for Beams A-6, B-6 and C-6 (steel reinforcement $3.62 \%$ ), noting that highest strain was recorded for C-6 and the lowest for B-6. From the above curves, we can guess the required ratios of reinforcement for each beam, as it will be discussed in the following point. 


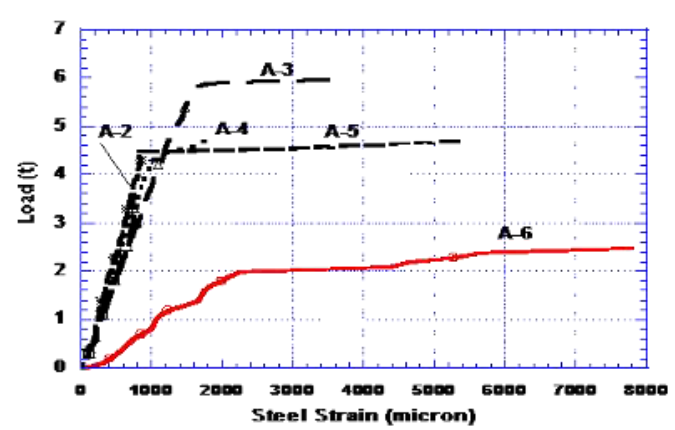

Fig. 12 Relations of load and strain of group A

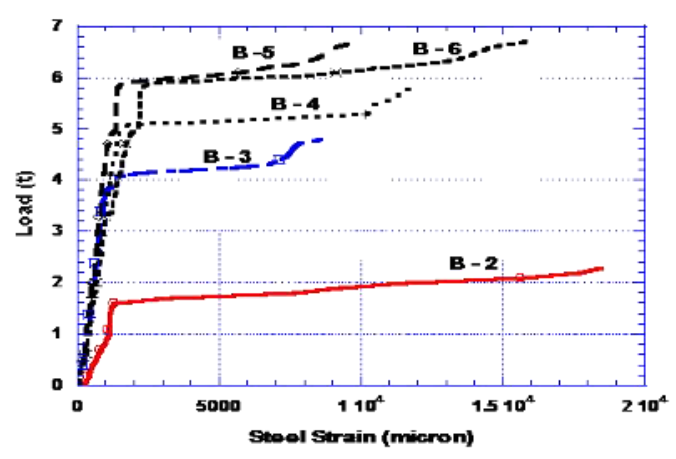

Fig. 13 Relations of load and strain of group B

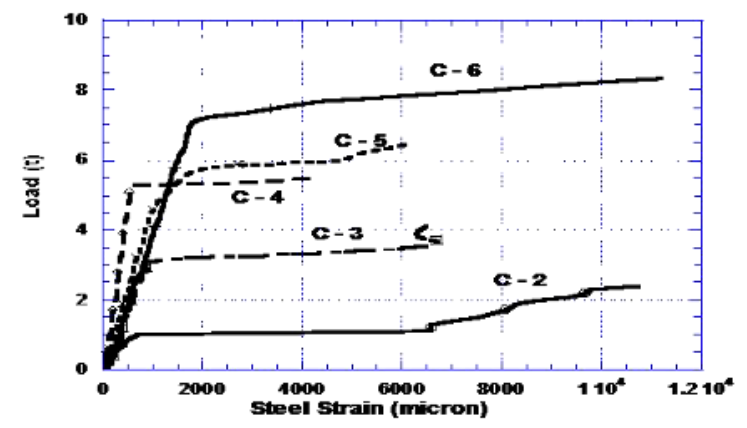

Fig. 14 Relations of load and steel strain of group C

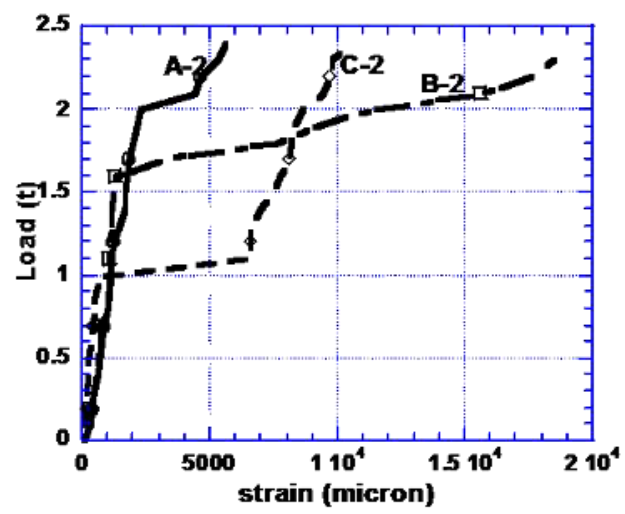

Fig. 15 Relation of load and strain of A-2, B-2, C-2

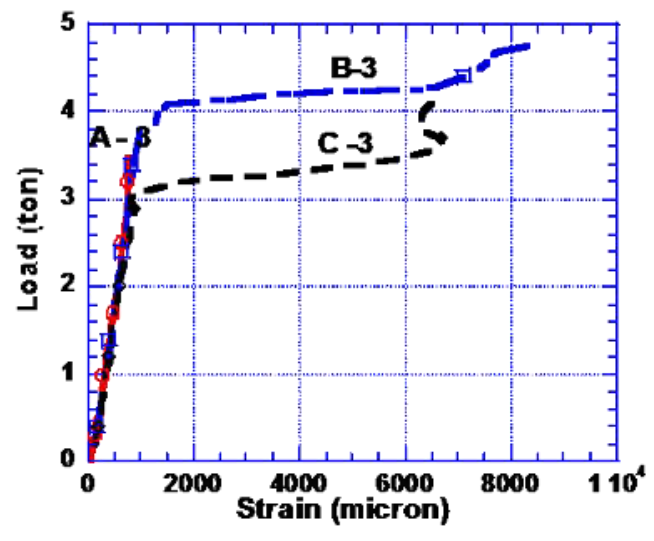

Fig. 16 Relation of load and strain of A-3, B-3, C-3 


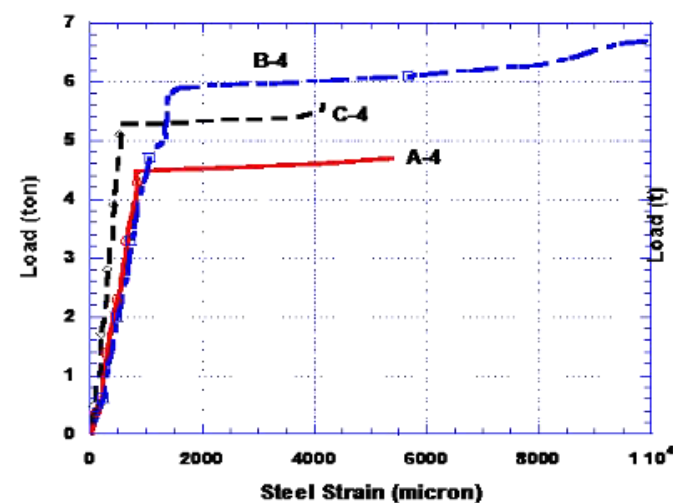

Fig.17 Relations of load and strain of A-4, B-4, C-4

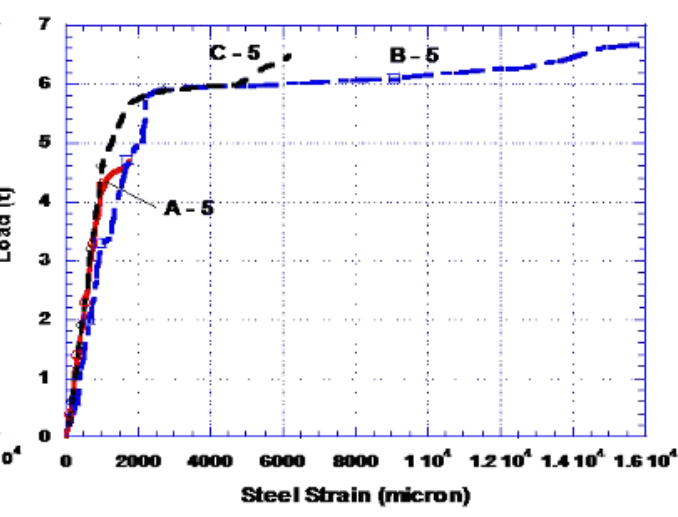

Fig.18 Relations of load and strain of

A-5, B-5, C-5

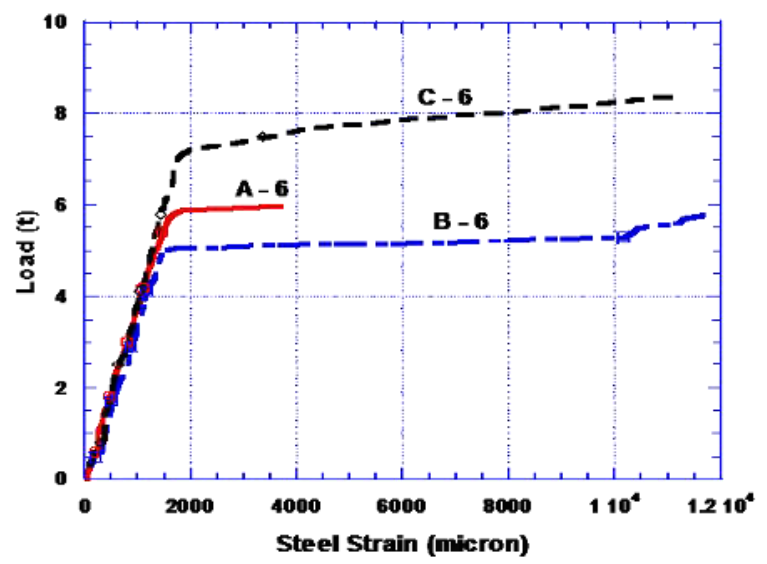

Fig. 19 Relations of load and steel strain of A-6, B-6 and C-6

\section{The Required Steel Reinforcement}

One of the main purposes of the current study is to establish the required reinforcement of flexural beams. This can be done by many methods such as:

1- Crack control. Fracture energy method is used which is a function of crack width

2- Maximum allowable deflection. In the Egyptian code of practice, maximum allowable deflection of simple beam is $L / 250$ where $L$ is the span of the beam. Figure 20 shows the maximum deflection of the tested beams as affected by steel reinforcement for different groups (A, B and C). Groups B and C of HSC have the same trend and close values of 
ultimate load at the same steel ratios. Fig. 21 illustrates the maximum load as affected by steel reinforcement. From figures 20 and 21 with the given results of failure mode, load deflection relations and from noticing the propagation of cracks and failure mode of beams and following the concept given in Fig. 22 ( $a$ and b), the required steel reinforcement are determined. For normal strength concrete, required steel ratio is given by the code, then at this value we determine the deflection at which we obtained the percentage of steel reinforcement for HSC beams. This concept is utilized in the study together with noticing the failure mode, crack propagation and the above results.

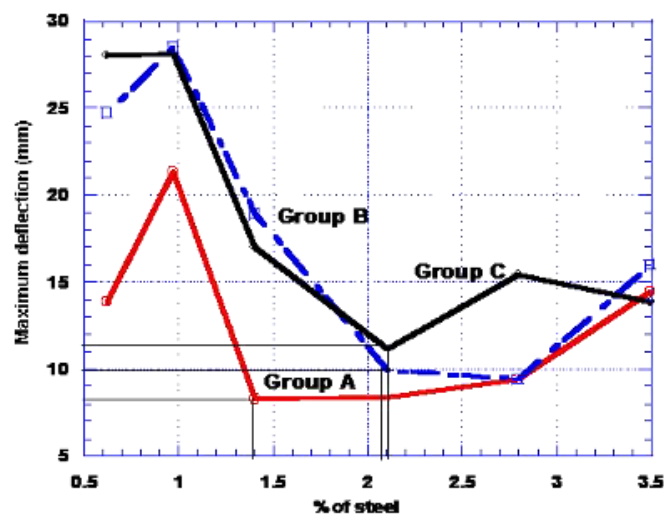

Fig.20 Relation of maximum deflection and steel ratio

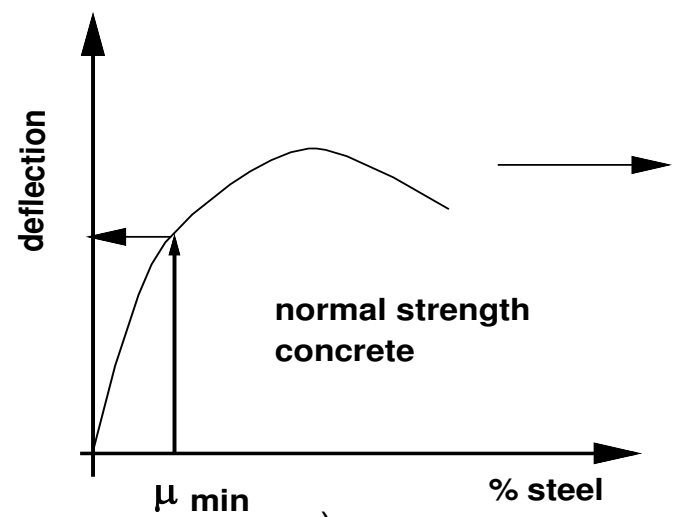

a)

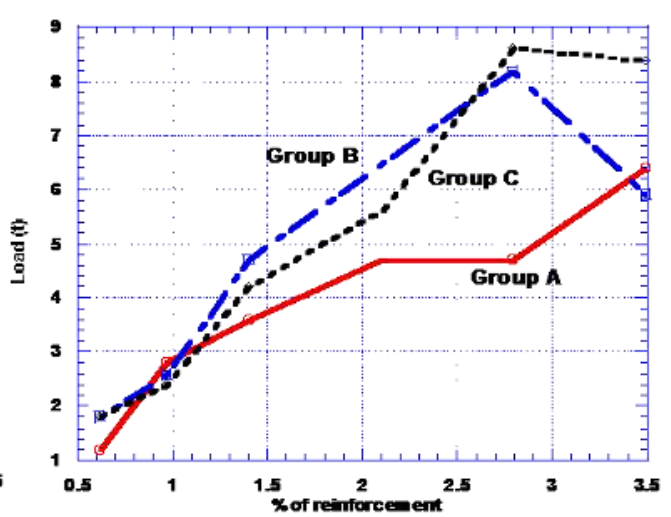

Fig. 21 Relation of maximum deflection and load

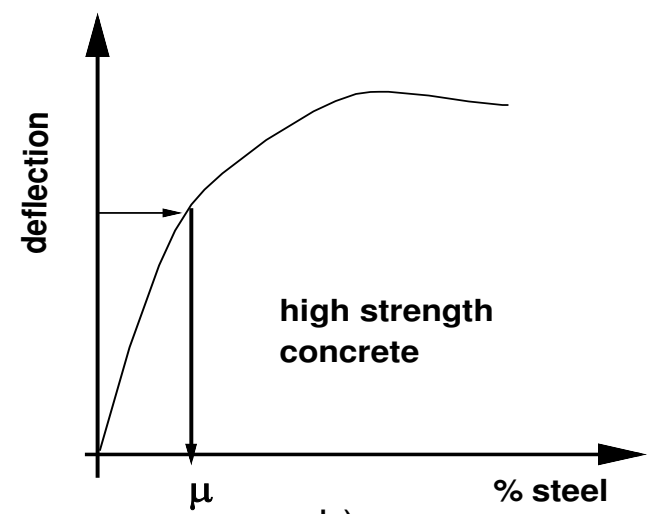

b)

Fig. 22 (a, b) A concept of determining the required reinforcement

From parametric analysis, the recommended percentages of steel reinforcement for analyzed beams are as follows:

For group A (C250): $\mathrm{A}_{\mathrm{s}}=1.45 \%, \stackrel{\text { leads to }}{\longrightarrow} \% A s_{\max }=0.0058 f_{c}$ 
For group B (C500): $\mathrm{A}_{\mathrm{s}}=2.1 \% \stackrel{\text { leadsto }}{\longrightarrow} \%$ As $\max =0.0042 f_{c}$

For group C (C700): $\mathrm{A}_{\mathrm{s}}=2.25 \% \stackrel{\text { leads to }}{\longrightarrow} \% A s_{\max }=0.0032 f_{c}$

Equation (1) agrees to a reasonable degree with the Egyptian code, which satisfies that the required percentage of steel reinforcement for steel $36 / 52$ equals $0.005 f_{c}$. Eqs. (2) and (3) are recommended for high strength concrete. From such results, the required steel reinforcement is represented by the following equation:

$\% A s_{\max }=[K] f_{c}$

Where, $\mathbf{K}$ is a factor, which depends on the grade of concrete (for steel grade $36 / 52)$ and $f_{c}$ is the grade of concrete $\left(\mathrm{kg} / \mathrm{cm}^{2}\right)$. The factor $\mathbf{K}$ can be obtained from Fig. 23 or from Eq. (5).

$$
K=0.0069164-5.3443 \times 10^{-6} f_{c} \text { With correlation coefficient } \mathrm{R}=0.999
$$

Equations 4 and 5 are applicable to all grades of concrete. The recommended equation for percentage of steel reinforcement does not include effect of size. To overcome such problem, analytical analysis is to be carried out in the following part

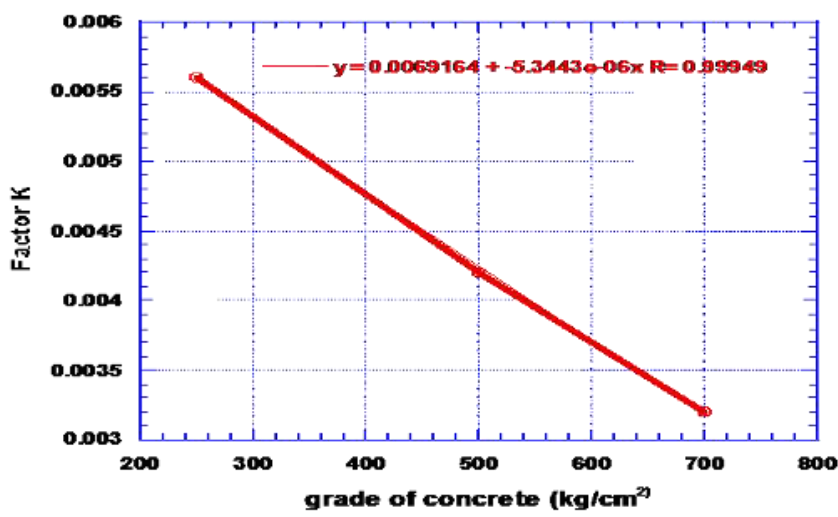

Fig. 23 Determination of Factor K of Eq. 5

\section{PART II: ANALYTICAL ANALYSIS}

\section{Finite Element Modeling of Normal and High strength concrete}

In a previous study, the author utilized a nonlinear two-dimensional finite element model to study the shear strength of HSC beams. The accuracy of the model was verified in Japan $[8,9]$. Nonlinear FE program called WCOMR $[9,10,11]$ was used to carry out the numerical calculation. Modeling of concrete 
for pre-cracking range is based on elasto-plastic fracture model, which was developed by Maekawa et al $[9,10,11,12]$. After cracking, the analysis is based on the smeared crack approach using the average stress-strain relationship of cracked concrete and reinforcing bars. The tension stiffening and softening model of concrete [9-12] has the following form:

$$
\sigma_{\mathrm{t}}=\mathrm{f}_{\mathrm{t}}\left(\varepsilon_{\mathrm{tu}} / \varepsilon_{\mathrm{t}}\right)^{\mathrm{C}}
$$

Where: $\sigma_{t}$ is the tensile stress normal to cracks, $f_{t}$ is the tensile strength of concrete, $\varepsilon_{\mathrm{t}}$ is the tensile strain normal to the crack, $\varepsilon_{\mathrm{tu}}$ is the cracking strain and $\mathrm{C}$ is a parameter describing the sharpness of the descending curve. For reinforced concrete, $\mathrm{C}$ is considered 0.4 [9, 10,11,12,13]. Fig. 24 illustrates the model used for tension softening -stiffening for reinforced concrete [9]. It is assumed that the shear transfer ability of cracked concrete losses and exhibits softening $[9,10,11,12,13]$. The shear-softening model is considered based on a model of An et al $[9,11,12,13,14]$ as follows:

$$
\imath=\imath_{\max }\left(\gamma_{\mathrm{u}} / \gamma\right)^{\mathrm{C}}
$$

where, $\gamma_{u}$ is the ultimate shear strain (taken as 0.004 for confined concrete or reinforced concrete and 0.04 for unconfined concrete or plain concrete) [8,9[, $\mathfrak{l}_{\max }$ is the maximum shear stress corresponding to ultimate shear strain and $\mathrm{C}$ is the same as tension stiffening parameter. More details regarding the model were given in references [8-14].

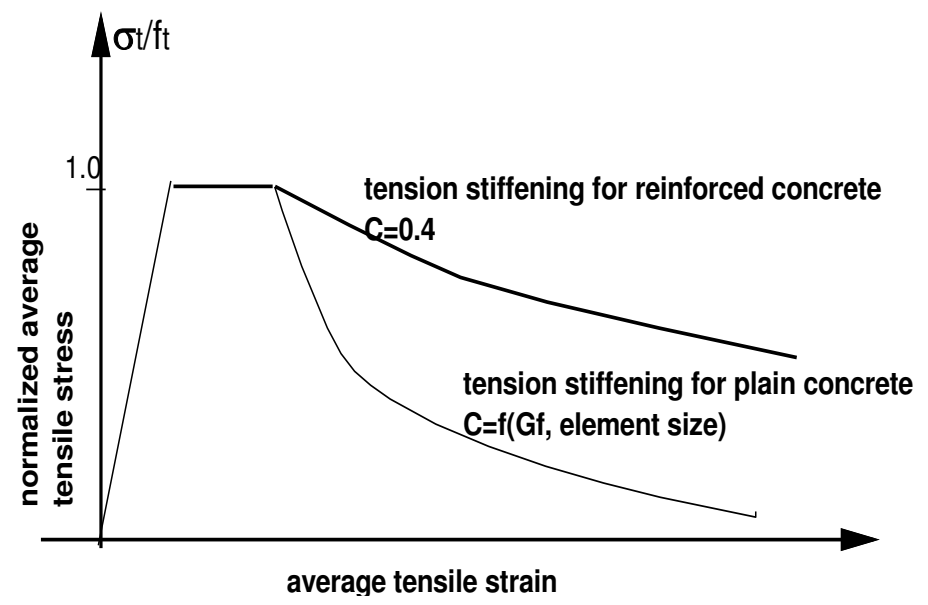

Fig. 24 Tension softening - stiffening model for plain and reinforced concrete

The post cracking mechanism of cracked concrete is established by considering two adjacent cracks as illustrated in Fig. 25. At this stage the cracks get final spacing as shown in Fig. 26 Figure 27 illustrates the tensile behavior of concrete between two adjacent cracks. The figure illustrates also the change of 
bond between steel bars and concrete. The average stress strain relationship of cracked concrete prior to yielding of reinforcement is taken as follows [8-14]:

$$
\mathrm{F}=(1 / 5)^{\mathrm{C}} \mathrm{f}_{\mathrm{t}}\left[5.5\left(\varepsilon / 5 \varepsilon_{\mathrm{tu}}\right)-4.5\left(\varepsilon / 5 \varepsilon_{\mathrm{tu}}\right)^{1.25}\right]
$$

Where, $\varepsilon_{\mathrm{tu}}$ is the cracking strain and $\mathrm{C}$ is the parameter of tension stiffening (larger than or equal to 0.4 based on crack direction). The accuracy of the proposed model was verified $[8,9]$. The model was proved to be suitable for analysis of normal and HSC.
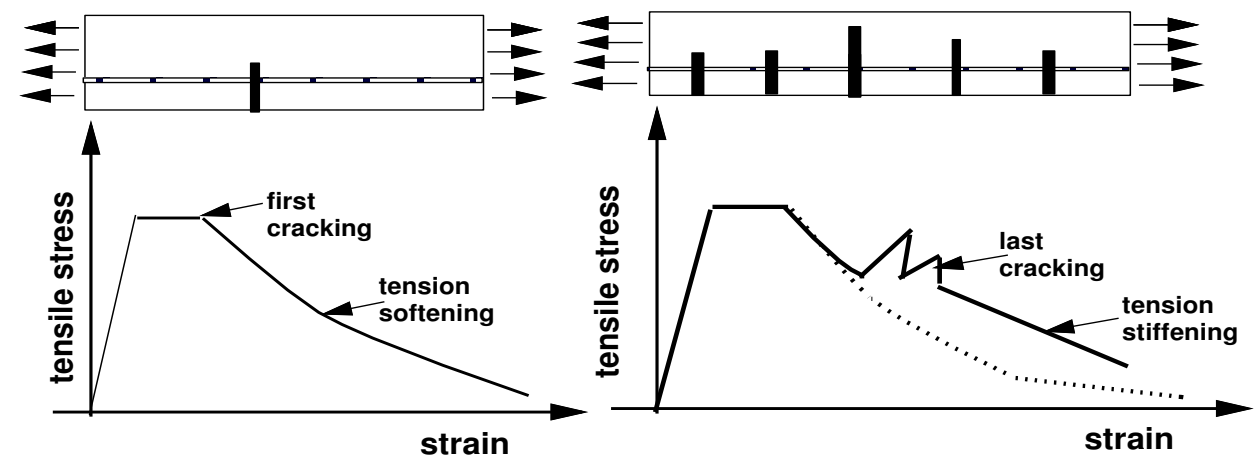

Fig. 25 Behavior at beginning of cracking Fig. 26 Behavior after propagation of cracks
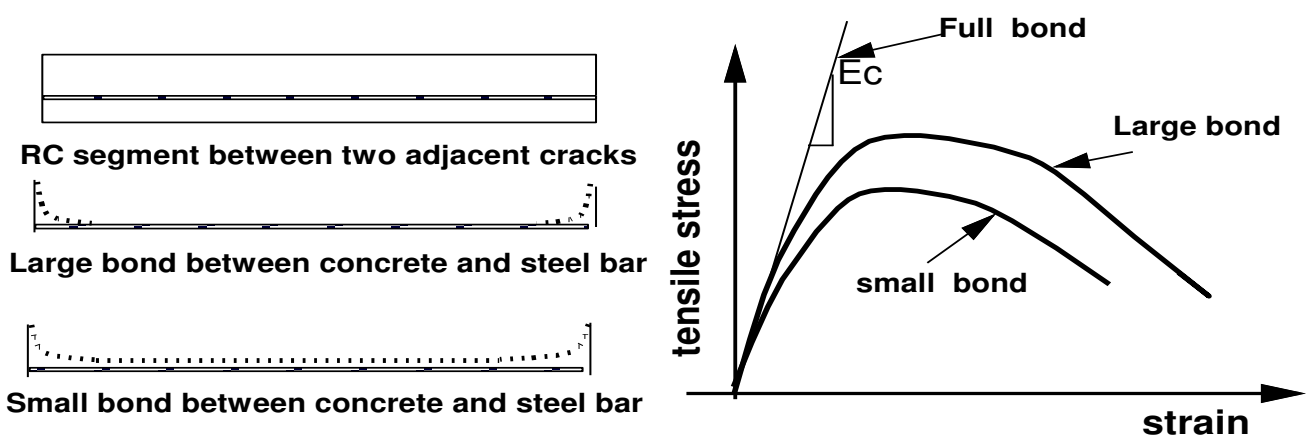

Fig. 27 Tensile behavior of concrete between two adjacent cracks

The model is used to analyze beams with different sizes and more details are found in Ref. [8]. In Ref. [8], the load deflection curves were given. Fig. 28 illustrates the dimensions and details of the beams. Table 4 illustrates the cases of study. Three groups were analyzed; group A, B and C. The difference between the groups is the percentage of steel. Each group has different steel ratios. All the analyzed beams have HSC of grade $500 \mathrm{~kg} / \mathrm{cm}^{2}$. Similar cases were analyzed for grade of $700 \mathrm{~kg} / \mathrm{cm}^{2}$. 


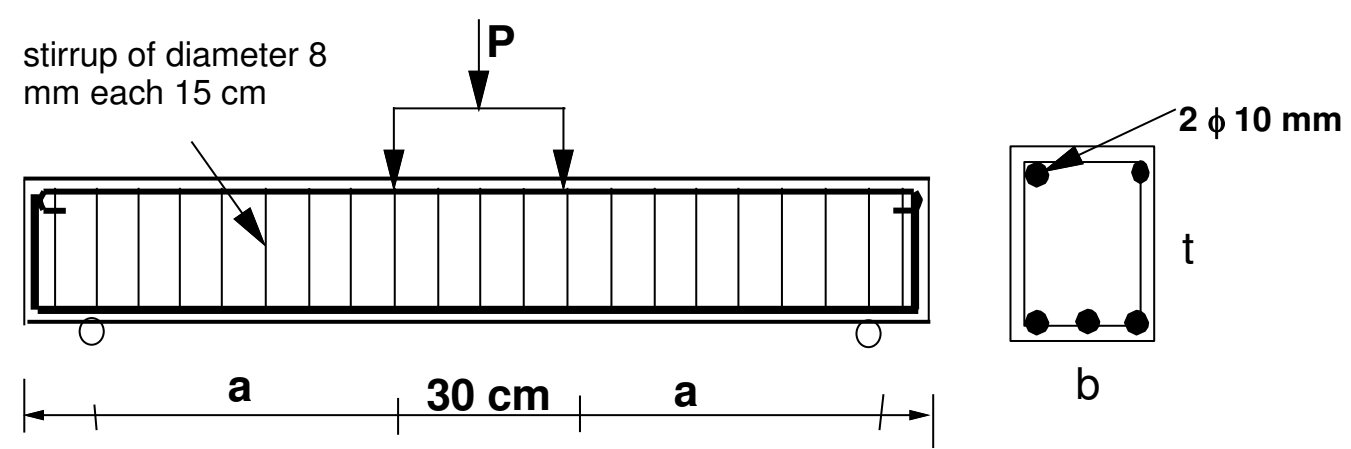

Fig. 28 Details of Analyzed Beams

Table 4 Cases of study of analytical results

\begin{tabular}{|c|l|l|l|l|l|l|l|l|l|}
\hline Group & beam & $\begin{array}{c}\mathrm{b} \\
(\mathrm{cm})\end{array}$ & $\begin{array}{c}\mathrm{t} \\
(\mathrm{cm})\end{array}$ & $\begin{array}{c}\text { Span } \\
\mathrm{L} \mathrm{cm})\end{array}$ & $\begin{array}{c}(\mathrm{a}) \\
\mathrm{cm}\end{array}$ & $\mathrm{a} / \mathrm{d}$ & $\begin{array}{c}\text { Reinft. } \\
\text { bars }\end{array}$ & $\%$ As & $\begin{array}{c}f_{c} \\
\mathrm{~kg} / \mathrm{cm}^{2}\end{array}$ \\
\hline \multirow{3}{*}{$\mathrm{A}$} & $\mathrm{a} 1$ & 10 & 10 & 120 & 40 & 4 & $2 \phi 10$ & 1.85 & 500 \\
\cline { 2 - 11 } & $\mathrm{a} 2$ & 10 & 20 & 160 & 60 & 4 & $2 \phi 10$ & 0.85 & 500 \\
\cline { 2 - 11 } & $\mathrm{a} 3$ & 10 & 40 & 200 & 80 & 4 & $2 \phi 10$ & 0.41 & 500 \\
\hline \multirow{3}{*}{ B } & $\mathrm{b} 1$ & 10 & 10 & 120 & 40 & 4 & $2 \phi 12$ & 2.65 & 500 \\
\cline { 2 - 10 } & $\mathrm{b} 2$ & 10 & 20 & 160 & 60 & 4 & $2 \phi 12$ & 1.22 & 500 \\
\cline { 2 - 10 } & $\mathrm{b} 3$ & 10 & 40 & 200 & 80 & 4 & $2 \phi 12$ & 0.59 & 500 \\
\hline \multirow{2}{*}{$\mathrm{C}$} & $\mathrm{c} 1$ & 10 & 10 & 120 & 40 & 4 & $3 \phi 12$ & 4.0 & 500 \\
\cline { 2 - 9 } & $\mathrm{c} 2$ & 10 & 20 & 160 & 60 & 4 & $3 \phi 12$ & 2.11 & 500 \\
\cline { 2 - 8 } & $\mathrm{c} 3$ & 10 & 40 & 200 & 80 & 4 & $3 \phi 12$ & 0.88 & 500 \\
\hline
\end{tabular}

Following the same method followed in the experimental part, the required quantity of steel reinforcement for different beams with different sizes were obtained as it is shown in Fig. 29. Due to limited space we give only the final results. The results of Fig. 29 can be summarized by the following equations similar to Eqs. 1, 2 and 3.

For C500

For beam depth $10 \mathrm{~cm}: \mathrm{A}_{\mathrm{s}}=1.95 \%, \stackrel{\text { leads } \text { to }}{\longrightarrow} \% A s_{\max }=0.0039 f_{c}$

For beam depth $20 \mathrm{~cm}: \mathrm{A}_{\mathrm{s}}=2.15 \%, \stackrel{\text { leads } \text { to }}{\longrightarrow} \% A s_{\max }=0.0043 f_{c}$

For beam depth $40 \mathrm{~cm}: \mathrm{A}_{\mathrm{s}}=2.35 \%, \stackrel{\text { leads to }}{\longrightarrow} \% A s_{\max }=0.0047 f_{c}$ 
For C700

For beam depth $10 \mathrm{~cm}: \mathrm{A}_{\mathrm{s}}=2.2 \%, \stackrel{\text { leads } \text { to }}{\longrightarrow} \% A s_{\max }=0.00325 f_{c}$

For beam depth $20 \mathrm{~cm}: \mathrm{A}_{\mathrm{s}}=2.35 \%, \stackrel{\text { leads to }}{\longrightarrow} \% A s_{\max }=0.0034 f_{c}$

For beam depth $40 \mathrm{~cm}: \mathrm{A}_{\mathrm{s}}=2.55 \%, \stackrel{\text { leads to }}{\longrightarrow} \% A s_{\max }=0.0037 f_{c}$

From the given equations, it is clear that the theoretical results agree to a reasonable degree with the experimental results. Also, the results show that as depth (size) of the beam increases, the required amount of steel reinforcement increases. This is because the brittleness increases with the increase of the size and hence bigger quantity of steel is needed to increase ductility. The effect of size on reinforcement of HSC beams is not included and should be considered.

\section{Recommended Model for Steel Reinforcement}

Based on the experimental results and theoretical results using finite element analysis, and by using parametric analysis and curve fitting (as shown in Fig.30), the following model is established to determine the recommended percentage of steel reinforcement of high strength concrete flexural beams considering the effect of size:

$$
\% A s_{\max }=[K\} f_{c}
$$

Where $f_{c}$ is the concrete strength in $\mathrm{kg} / \mathrm{cm}^{2}$

$\mathrm{K}$ is a factor, which depends on size of the cross section as follows:

$K=0.0069164-5.3443 \times 10^{-6} f_{c} \quad$ For all grades of concrete (size is not considered)

$K=\left\{0.0038+2.4 \times 10^{-5} h\right\} f_{c} \quad$ For C500 (size of cross section is considered)

$K=\left\{0.003+1.7 \times 10^{-5} h\right\} f_{c} \quad$ For C700 (size of cross section is considered)

Where $h$ is the depth of the cross section in $(\mathrm{cm})$.
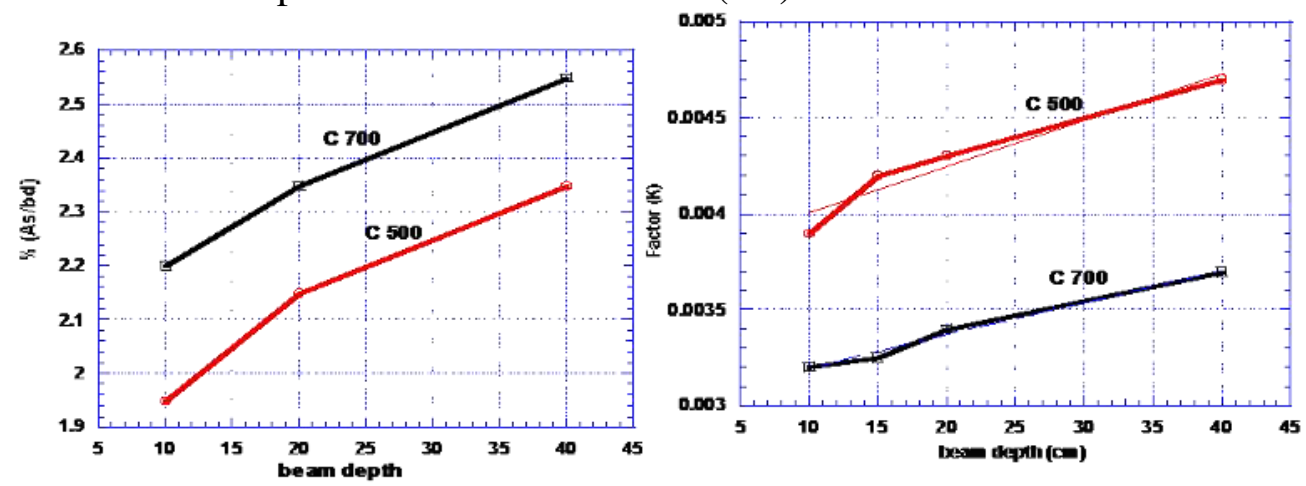

Fig. 29 Recommended steel reinforcement of beams Fig. 30Factor [K] in Eq. 15 


\section{SUMMARY AND CONCLUSIONS}

In the current study, experimental and analytical analyses were carried out to propose the maximum requirements of reinforcement for high strength concrete flexural beams and to compare the behavior of HSC beams with that of normal strength concrete beams. The behavior is represented by failure mode, ultimate load, deflection and strain. From the study and from the parametric analysis, the following points are concluded: -

1- Low grades of steel are not suitable to be used with high strength concrete.

2- The failure mode of HSC beams is relatively different than that of normal strength beams and this is mainly due to the higher degree of brittleness of HSC. High strength beams require more quantity of steel reinforcement to increase the ductility in such a way that brittle failure should be avoided.

3- Using HSC leads to an increase of the cracking and ultimate loads of beams and a decrease of ductility beams. The steel reinforcement of HSC beams should be increased in such a way that yielding of steel should occur first before crushing of concrete to avoid brittle failure.

4- From the given results of failure mode, load deflection relations and from noticing the propagation of cracks and failure mode of beams and following the concept of maximum steel reinforcement which is given by the code for normal strength concrete, the required reinforcement of HSC flexural beams is determined. The maximum reinforcement ratio is represented by:

$$
\% A s_{\max .}=[K] f_{c}
$$

Where $\mathrm{K}$ is a factor, which depends on the grade of concrete (for steel grade $36 / 52)$ and $f_{c}$ is the grade of concrete $\left(\mathrm{kg} / \mathrm{cm}^{2}\right)$. The factor $\mathrm{K}$ can be obtained as: $K=0.0069164-5.3443 \times 10^{-6} f_{c}$

The above equations are applicable to all grades of concrete.

5- The maximum steel ratio is usually dependent on the size. Analytical analysis was carried out to consider the effect of size of cross section on the required reinforcement. Nonlinear plane stress finite element model is utilized to give the required steel reinforcement considering the size effect. In the current study, the size is considered through changing the depth of the section.

6- Based on experimental and theoretical results and by using parametric analysis and curve fitting, the final recommended model of the maximum reinforcement of high strength concrete flexural beams considering the effect of size is as follows:

$\% A s_{\text {max }}=[K\} f_{c}$, Where, $f_{c}$ is the concrete strength in $\mathrm{kg} / \mathrm{cm}^{2}$,

$\mathrm{K}$ is a factor, which depends on size of the cross section as follows: 
$K=0.0069164-5.3443 \times 10^{-6} f_{c} \quad$ For all grades of concrete (size is not considered)

$K=\left\{0.0038+2.4 \times 10^{-5} h\right\} f_{c} \quad$ For C500 (size of cross section is considered)

$K=\left\{0.003+1.7 \times 10^{-5} h\right\} f_{c} \quad$ For C700 (size of cross section is considered)

Where $\mathrm{h}$ is the depth of the cross section in $(\mathrm{cm})$. The models are recommended to be included in design of high strength flexural beams.

7- The effect of compression steel is not included. In the current study, effect of size is included through changing of beam depth only, however it can be done through changing the shear -span to depth ratio or changing the beam breadth. The recommended model needs to be checked with the calculations of strain compatibility. These points should be included in further study.

\section{REFERENCES}

1- "High-Performance Concretes" A State-of-Art Report (1989-1994) from the Internet

2- Megahid and Khairy "Static Behavior of RC Column Joints as Affected by Changing of its Grade of Concrete and Details of Reinforcement" Journal of Engineering Sciences, Assiut University, Vol. 34, No. 5, pp. 1-23, Sept. 2006

3- Yan H. et al "High Strength Concrete Short Beams Subjected to Cyclic Loading" ACI Structural Journal, May-June 1999, pp. 392-399

4- Bosco et al "Minimum Reinforcement in High Strength Concrete" Journal of Structural Engineering, Vol.116, No.2, Feb.1990, 427-437

5- Design of concrete structures, Part 1, Eurocode, No.2, 1988 (Recited from 1)

6- Building Code Requirements of RC, ACI-318-83, 1983, ACI

7- Bosco et al "Fracture of Reinforced concrete: Scale effect and snap back instability" Int. Conference on Fracture Damage of Concrete" Vienna, Austria, 1988

8- Khairy Hassan A., "Finite Element Study on Shear Behavior of RC Beams with HSC" $1^{\text {st }}$ Int. conference of civil Eng. Science" ICCES1, Vol.1, 835-845, Oct. 2003

9- Denpongpan et al. "Effect of Reversed Loading on Shear Behavior of Reinforced Concrete" Eighth East Pacific conf. on St.Eng., EASEC-8, Singapore, Dec. 2001

10- Okamura and Maekawa "Nonlinear Analysis and Constitutive Models of Reinforced Concrete" Printed in JAPAN, 1991

11- Maekawa et al "WCOMR. Finite Element program "Tokyo University, Japan, 1999 
12- Maekawa and Amorn "Shear Failure of pre-cracked reinforced concrete beams" $8^{\text {th }}$ East Pacific conf. On Structural Engineering, EASEC-8, Singapore, Dec. 2001

13- Mohamed et al "Flexure-shear Model for prevention of diagonal Failure in beams with HS Concrete". $8^{\text {th }}$ East Pacific conf. on St. Eng., EASEC8, Singapore, Dec. 2001

14- Ho et al "Nonlinear flexural Behavior of reinforced and HSC Beams" $8^{\text {th }}$ East Pacific conf. On Structural Engineering, EASEC-8, Singapore, Dec. 2001

\section{دراسة معملية ونظرية عن نسب حديد التسليح القصوى للكمرات الخرسانية المسلحة} ذات الخرسانة عالية المقاومة والمعرضة للانحناء

في هذا البحث نم إجراء دراسة معملية ونظرية لتحديد نسب حديد التسليح القصوى للكمرات الخرسانية

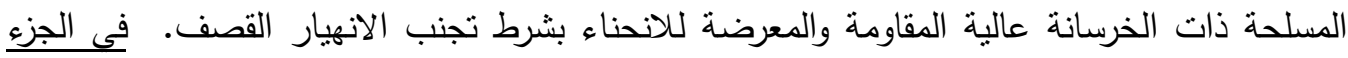
الأول من الدراسة نم صب عدد 18 كمرة من خرسانات ذات رتب مختلفة. نم تقسيم الكمرات إلى ثلاث

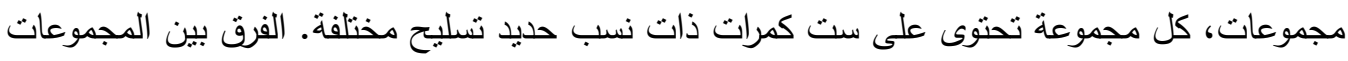

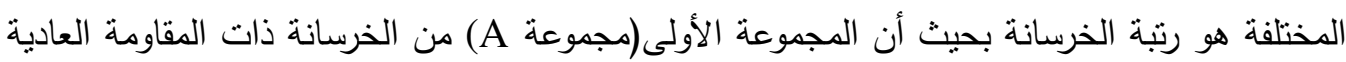

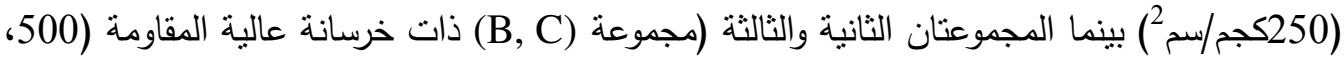

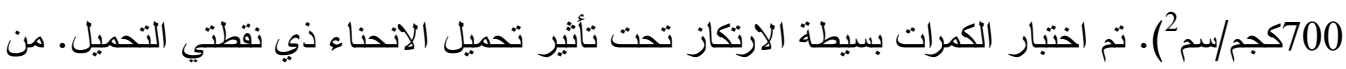

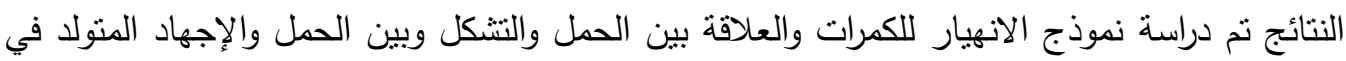
الحديد.

لقد ثبت أنه كلما زادت مقاومة الخرسانة زادت قصافة الخرسانة وبالتالي نزيد نسبة حديد التسليح

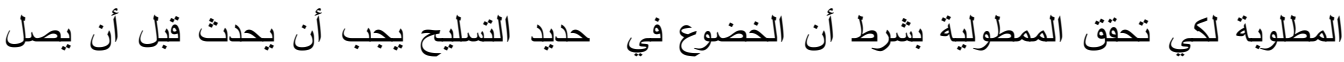
إجهاد الضغط في الخرسانة لأقصى قيمة حتى نمنع حدوث الانهيار القصف. من مقارنة سلوك الكمرات

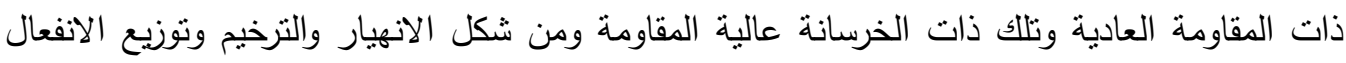

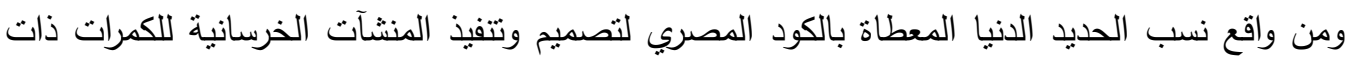
المقاومة العادية وربط ذلك بالكمرات ذات الخرسانة عالية المقاومة ومن واقع دراسة المتغيرات أمكن

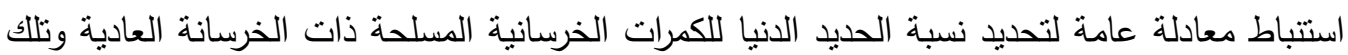

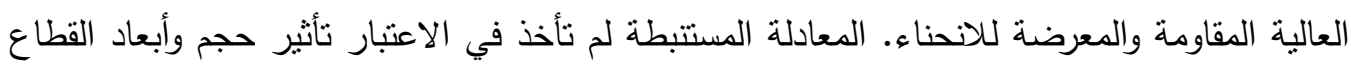

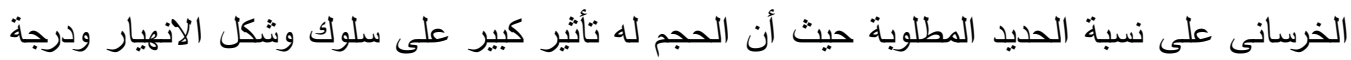
القصافة والممطولية ومقاومة الخرسانة وخاصة ذات المقاومة العالية. ولذلك نم إجراء دراسة نظرية باستخدام نموذج نظري مبنى على نظرية العناصر المحددة اللاخطية الثنائية الأبعاد. النموذج المستخدم 
تم التأكد من دقته في أبحاث سابقة وهو مستحدث لدراسة سلوك العناصر المسلحة ذات الخرسانة العادية وتلاك العالية المقاومة. لقد نم دراسة عدد 18 كمرة ذات خرسانة عالية المقاومة (500، 700كجم/سم²). من واقع دراسة المتغيرات أمكن استتباط معادلة عامة لتحديد نسبة الحديد القصوى للكمرات الخرسانية

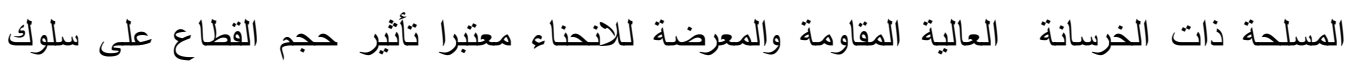
الكمرات ونسبة الحديد المطلوبة. إن النموذج المستتتج يصلح للكمرات الخرسانية المسلحة ذات الخرسانة العادية وتلك ذات رنبة الخرسانة العالية والمعرضة للانحناء ويأخذ في الاعتبار تأثثر الحجم وينصح باستخدامه في تصميم تلك العناصر الإنشائية. 